\title{
ANALISIS NUMERIK SIMULASI KINERJA SISTEM TATA UDARA UNITARY MENGGUNAKAN LIQUID-SUCTION HEAT EXCHANGER DENGAN REFRIGERAN HIDROKARBON
}

\author{
${ }^{(1)}$ Nuriyadi Muhammad \\ E-mail: nuriyadi@polban.ac.id \\ ${ }^{1)}$ Teknik Refrigerasi dan Tata Udara Politeknik Negeri Bandung, \\ Jl. Gerlong Hilir, Ciwaruga, Bandung \\ Telp: (022) 2013789,081320080033
}

\begin{abstract}
One of the environmental issue to be addressed, particularly in the field of refrigeration and air conditioning, is the destruction of the ozone layer and the effects of global warming due to the use of environmentally inefficient refrigerants. In the field of Refrigeration and Air Conditioning, refrigerant as a cooling medium, plays an important role, and until now there are still the use of refrigerant materials that are not environmental friendly, generally synthetic refrigerant. One alternative refrigerant replacement against the synthetic refrigerant is hydrocarbon refrigerant $(H C)$. On the other hand several ways can improve the performance of refrigeration system by lowering the temperature of liquid line using liquid to suction heat exchanger. In this study a numerical simulation was conducted to examine the effect of using liquid to suction heat exchanger on the performance of a unitary air-conditioning system using hydrocarbon refrigerant as a coolant fluid. The results are, liquid to suction heat exchanger increase refrigeration effect by raising of heat exchanger effectivity, the highest increasing is about 7\%. But the use of LSHX also rise up the compression work by increasing of heat exchanger effectivity by 19\%. So the Coefficient of performance (COP) and relative capacity index decrease by 5\%. Decreasing of performance is higher in the unit that operates at higher temperature.
\end{abstract}

\section{keywords: Liquid-Suction Heat Exchanger, Performance of AC unitary, Hidrocarbon refrigerant.}

\begin{abstract}
ABSTRAK
Perkembangan teknologi yang lebih efisien hemat energi serta ramah lingkungan semakin diperlukan. Salah satu isu lingkungan yang menjadi pembicaraan, khususnya dalam bidang refrigerasi dan tata udara (RTU), adalah perusakan lapisan ozon dan efek pemanasan global akibat penggunaan refrigeran yang tidak ramah lingkungan. Dalam bidang Refrigerasi dan Tata Udara, refrigeran sebagai media pendingin, memegang peranan penting, dan sampai saat ini masih terdapat penggunaan bahan refrigeran yang tidak ramah lingkungan, umumnya refrigeran sintetis/buatan. Salah satu alternatif refrigeran pengganti terhadap refrigeran sintetis tersebut adalah refrigeran hidrokarbon (HC). Di sisi lain beberapa cara dapat meningkatkan kinerja sistem refrigerasi, antara lain dengan menurunkan tekanan dan temperatur kerja kondenser menggunakan liquid to suction heat exchanger. Pada penelitian ini dilakukan simulasi numerik untuk mengkaji pengaruh penggunaan liquid to suction heat exchanger terhadap kinerja dari sistem tata udara unitary yang menggunakan refrigeran hidrokarbon sebagai fluida pendingin. Hasil dari analisis numerik dan simulasi kinerja sistem tata udara unitary menggunakan Liquid-Suction Heat Exchanger dengan refrigeran hidrokarbon ini adalah bahwa penggunaan Liquid-Suction Heat Exchanger dapat meningkatkan efek refrigerasi refrigeran hidrokarbon sampai 7\%, menaikkan kerja kompresi refrigeran sampai 19\%, menurunkan COP sistem, dan menurunkan kapasitas pendinginan sekitar 5\%. Juga diperoleh bahwa penurunan kinerja lebih besar terjadi pada sistem dengan temperatur kondensasi yang lebih tinggi.
\end{abstract}

Kata Kunci: Liquid-Suction Heat Exchanger, Kinerja AC unitary, Refrigeran Hidrokarbon.

\section{PENDAHULUAN}

Sistem tata udara digunakan secara luas pada bangunan perkantoran, komersial, hunian, maupun fasilitas umum. Pada daerah tropis seperti Indonesia yang memiliki temperatur dan kelembaban rata-rata harian yang tinggi, mesin tata udara digunakan untuk memberikan 
kenyamanan kepada manusia (penghuninya). Secara umum, temperatur udara ruangan optimum untuk hunian manusia pada daerah tropis adalah $25 \pm 1{ }^{0} \mathrm{C}$ dengan kelembaban relatif $50 \pm 5 \%$. Mesin tata udara jenis split (split $A C$ system) merupakan salah satu jenis mesin tata udara unitary yang paling mudah dijumpai. Jenis ini pada umumnya memiliki kapasitas pendinginan kecil sampai menengah. AC split memiliki dua bagian utama, yakni indoor unit dan outdoor unit. Indoor unit dipasang di dalam ruangan yang dikondisikan, dan terdiri atas kipas dan koil evaporator. Outdoor unit atau juga dikenal sebagai condensing unit terletak di luar ruangan yang dikondisikan, dan terdiri atas kompresor dan kondenser. [1].

Banyaknya pemakaian mesin AC mengakibatkan konsumsi daya dan energi listrik yang besar pada bangunan hunian maupun komersial. Daya listrik yang digunakan oleh mesin tata udara merupakan penjumlahan dari konsumsi daya kompresor, kipas kondenser, kipas evaporator, dan peralatan kontrol. Sebagian besar konsumsi daya listrik mesin tata udara diambil oleh kompresor dan konsumsi energi ini dipengaruhi oleh kondisi operasi mesin tata udara dan tekanan kerja refrigerannya. Kebanyakan AC split menggunakan refrigeran R-22 sebagai fluida pendingin.

Dalam bidang penggunaan energi saat ini, dimana ketersediaan energi semakin menipis, diperlukan penghematan dalam pemakaian energi. Perkembangan teknologi yang lebih efisien hemat energi serta ramah lingkungan semakin diperlukan.

Salah satu isu lingkungan yang menjadi pembicaraan, khususnya dalam bidang refrigerasi dan tata udara (RTU), adalah perusakan lapisan ozon dan efek pemasanan global akibat penggunaan refrigeran yang tidak ramah lingkungan. Hal ini, kemudian mendorong negara-negara di dunia untuk kemudian bersama-sama melakukan pencegahan dan perbaikan dengan membuat kesepakatan ("protocol") yang kemudian dikenal dengan konvensi Wina pada tahun 1985, diikuti dengan protokol Montreal tahun 1987. Dalam perkembangannya kemudian tahun 2007, negaranegara yang tergabung dalam konvensi ini memutuskan untuk mempercepat proses penghapusan bahan-bahan yang merusak lingkungan.

Dalam bidang Refrigerasi dan Tata Udara, refrigeran sebagai media pendingin, memegang peranan penting, dan sampai saat ini masih terdapat penggunaan bahan refrigeran yang tidak ramah lingkungan, salah satunya adalah R22, atau umumnya refrigeran sintetis/buatan. Refrigeran ini mempunyai nilai ODP (Ozone Depletion Potential) dan GWP (Global Warming Potential) yang cukup tinggi. ODP merupakan ukuran relatif tingkat perusakan ozon suatu bahan terhadap tingkat perusakan ozon oleh refrigeran R11. Sedangkan GWP adalah ukuran relatif potensi penghasil efek pemanasan global/rumah kaca terhadap potensi efek rumah kaca akibat $\mathrm{CO}_{2}$. Salah satu alternatif refrigeran pengganti terhadap refrigeran sintetis tersebut adalah refrigeran hidrokarbon (HC).

Refrigeran Hidrokarbon mempunyai beberapa keunggulan diantaranya ramah lingkungan dan dapat menggantikan refrigeran sebelumnya, tanpa harus mengganti komponen. Dengan keunggulan tersebut, permintaan terhadap refrigeran hidrokarbon semakin meningkat. R22 mempunyai nilai ODP yang rendah, tepatnya sama dengan 0,055 tetapi mempunyai GWP yang tinggi sebesar 1700 . Sebagai alternatif penggantinya adalah refrigeran Hidrokarbon Propana (R290). Refrigeran Hidrokarbon memiliki densitas yang lebih kecil (sekitar setengah dari densitas R-22), hal ini akan mengakibatkan kebutuhan pengisian refrigeran menjadi lebih sedikit, sekaligus turunnya laju aliran massa refrigeran pada sistem pendingin. Dengan demikian kapasitas pendinginan dan konsumsi daya untuk kompresi juga akan turun. Turunnya daya kompresi merupakan keuntungan, namun turunnya kapasitas pendinginan mengakibatkan naiknya waktu operasional (operating time) dari sistem yang akan menaikkan konsumsi energi.

Ada beberapa cara yang dapat digunakan untuk meningkatkan kinerja sistem refrigerasi, antara lain dengan menurunkan tekanan dan temperatur kerja kondenser. Penurunan temperatur kerja kondenser dapat dicapai dengan berbagai cara, antara lain dengan memberikan pendinginan kepada refrigeran pada sisi tekanan tinggi. Metode pendinginan yang dapat dilakukan antara lain adalah dengan menambah kapasitas kipas kondenser, memberikan pendinginan awal kepada refrigeran yang akan memasuki kondenser dan menggunakan liquid to suction heat exchanger. Pendinginan dengan liquid to suction heat exchanger ( $L S H X)$ atau juga biasa disebut liquid to gas heat exchanger, memanfaatkan temperatur refrigeran keluaran evaporator yang rendah untuk menambah derajat subcool yang lebih besar, sehingga memberikan 
efek refrigerasi yang lebih besar pula. Heat exchanger digunakan antara liquid line dan suction line. Dengan adanya komponen ini keadaan refrigeran pada liquid line menjadi subcool dan keadaan refrigeran pada suction line menjadi superheat, dengan bertambahnya subcool maka kapasitas pendinginan akan naik sehingga performansi/kinerja sistem akan meningkat.

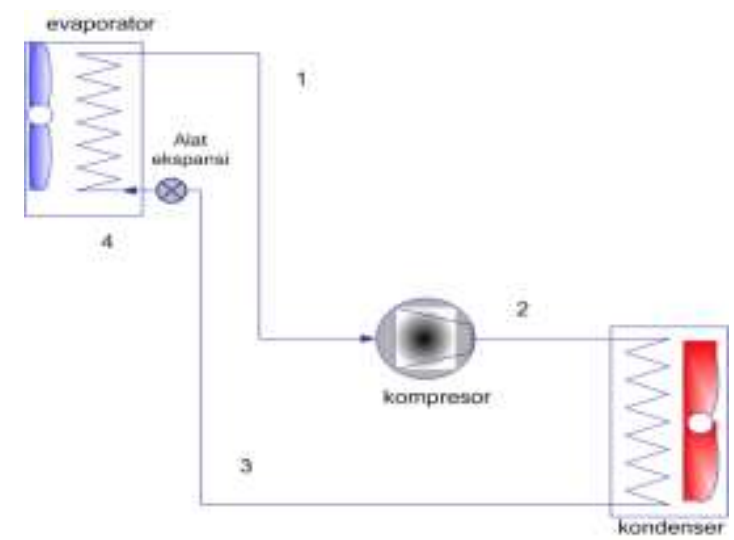

Gambar 1. Sistem Refrigerasi AC Unitary

Dengan meningkatnya kinerja sistem tersebut, maka akan terjadi penurunan konsumsi energi pada pengoperasian mesin tata udara ini.

Meningkatnya kapasitas pendinginan dengan subcooling dan superheating dapat dijelaskan dengan diagram tekanan entalpi. Akibat adanya pertukaran kalor pada LSHX, temperatur refrigeran keluaran evaporator akan naik dari kondisi 1 ke 1'. Pada keluaran kondenser, temperatur refrigeran cair akan turun dari kondisi 3 ke 3'. Kenaikan temperatur refrigeran keluaran evaporator dan penurunan temperatur refrigeran pada keluaran kondenser akibat penambahan $L S H X$ akan meningkatkan efek refrigerasi.

Namun, cara ini juga akan memberikan derajat superheat yang tinggi kepada refrigeran yang keluar dari evaporator sehingga temperatur refrigeran akan naik.

\section{LANDASAN TEORI}

Penelitian tentang liquid-suction heat exchanger (LSHX) untuk meningkatkan kinerja mesin refrigerasi telah dimulai oleh beberapa peneliti. Hasil kajian ini menunjukkan (gambar 2) bahwa performansi (COP) sistem refrigerasi dipengaruhi oleh efektifitas Heat Exchanger. Pada beberapa jenis refrigeran COP mengalami kenaikan namun ada juga yang mengalami penurunan.

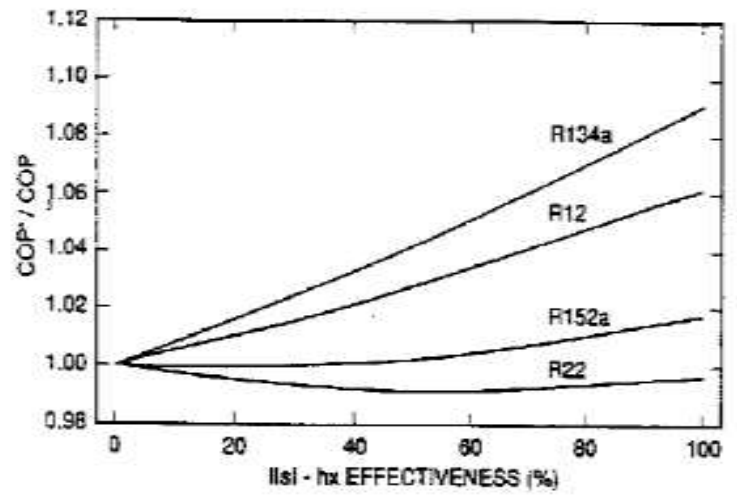

Gambar 2. Grafik Hubungan antara Efektifitas Heat Exchanger terhadap Perubahan COP

Kajian tersebut juga menyatakan bahwa salah satu faktor penting yang menentukan keuntungan penggunaan LSHX adalah properti dari refrigeran khususnya Panas jenis fluida. Gambar 3. menunjukkan pengaruh Kapasitas panas refrigeran pada kondisi Uap jenuh terhadap perubahan kinerja (COP) dari sistem refrigerasi.

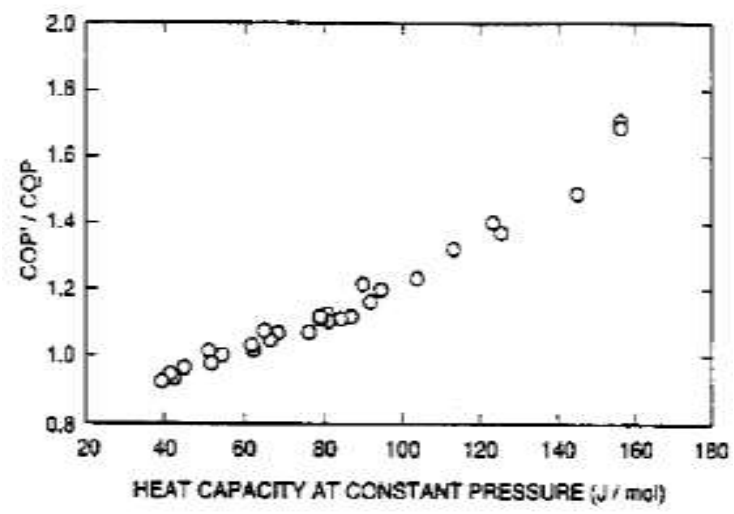

Gambar 3. Grafik Hubungan antara Kapasitas panas jenis Refrigeran terhadap Perubahan COP.

S.A. Klein (2000) menyatakan bahwa penggunaan LSHX pada beberapa jenis refrigeran ada yang menguntungkan namun ada juga yang merugikan. Gambar 6 menunjukkan pengaruh efektifitas LSHX terhadap Relative Capacity Index pada beberapa jenis refrigeran pada temperatur evaporasi $-20 \mathrm{oC}$ dan temperatur kondensasi $40 \mathrm{oC}$ yang akan mempengaruhi kapasitas pendinginan dari refrigeran. 


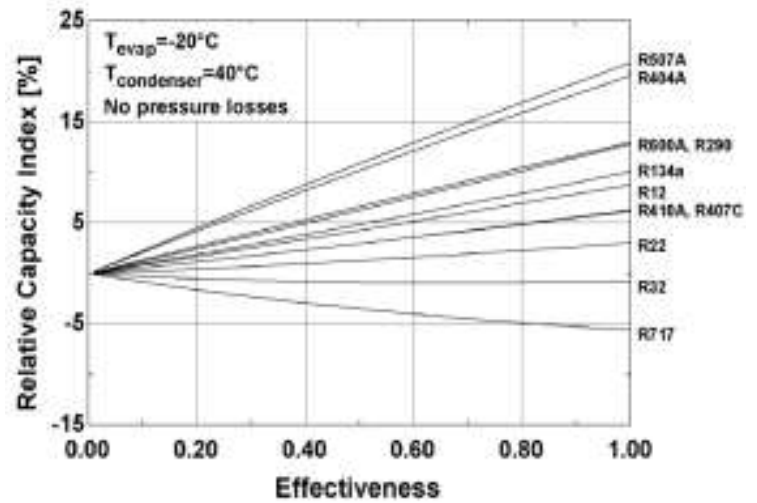

Gambar 4. Relative Capacity Index Sebagai fungsi dari Efektifitas LSHX

Stoecker dan Walukas telah melakukan simulasi untuk mengetahui pengaruh penggunaan LSHX pada sistem refrigerasi dengan evaporator tunggal dan evaporator ganda menggunakan refrigeran campuran. Hasil analisis mereka menunjukkan bahwa penggunaan LSHX dengan refrigeran campuran dapat meningkatkan kinerja mesin lebih baik dibandingkan dengan pada penggunaan refrigeran tunggal. McLinden (1990), melalui simulasi yang dilakukannya menyatakan bahwa penggunaan LSHX dapat meningkatkan kinerja mesin akibat kenaikan kalor jenis gas refrigeran. Domasnki dan Didion (1993) telah melakukan kajian untuk mengamati pengaruh penggunaan LSHX pada Refrigeran $\mathrm{R}$ 22 dan pengganti alternatifnya. Penelitian ini dikembangkan dengan melakukan kajian pada 29 jenis refrigeran oleh Domanski, Didion, dan Doyle (1994) dan Domanski (1995). Simulasi yang dilakukan oleh Bivens et al. pada tahun 1994 menyatakan bahwa penggunaan LSHX mampu meningkatkan kinerja mesin refrigerasi sebesar 6\% dengan menggunakan refrigeran campuran. Bittle et al (1995) melakukan eksperimen dengan R152a dan membandingkannya dengan R12 yang telah dilarang. Penelitian ini dikembangkan lagi oleh Bittle et al (1995b) dengan menggunakan refrigeran R507A, R404A, R600, R290, R134a, R407C, R410A, R12, R22, R32, dan R717. Kim dkk (1997) mengamati bahwa mesin refrigerasi dengan R22 hanya dapat sedikit meningkatkan kinerja pada superheat dan subcooling diset pada kisaran 20C.
Hasil simulasi yang dilakukan oleh Klein et al (2000) menunjukkan bahwa secara umum penggunaan LSHX akan meningkatkan kinerja suatu mesin refrigerasi pada kebanyakan refrigeran. Namun, hal ini tidak berlaku pada R22, R32, dan R717. Hasil ini sekaligus menunjukkan bahwa secara termodinamika penggunaan LSHX pada sistem refrigerasi tidak akan memberikan keuntungan berarti pada mesin yang menggunakan R22, R32, dan R717. Hasil yang sedikit berbeda ditunjukkan oleh simulasi YanaMotta dan Domanski (2000) yang menyatakan bahwa penggunaan LSHX dapat menaikkan kinerja mesin sampai $2 \%$, khususnya pada temperatur lingkungan yang tinggi. Eksperimen dengan AC mobil menggunakan refrigeran R134a oleh Li dkk. (2003) menyatakan bahwa penggunaan LSHX dapat meningkatkan kapasitas dan koefisien kinerja AC mobil. Dhanakitt (2003) dalam tesisnya menjelaskan bahwa penggunaan LSHX dapat menurunkan konsumsi energi AC split kapasitas $3.5 \mathrm{~kW}$ dengan payback period 2.74 tahun. Penelitian Dhanakit dilakukan dengan pengaturan temperatur ruangan pada satu harga saja, yaitu 26 0C. Penggunaan LSHX pada peralatan pendingin skala rumah tangga juga telah dilaporkan oleh Dagilis dkk. (2004) dengan fokus tinjauan pada desain LSHX yang optimal. Penggunaan LSHX pada peralatan refrigerasi kompresi dengan R22, R134a, dan R407 telah diteliti oleh Navaro-Esbria dkk (2005), dengan fokus penelitian pada pengaruh laju aliran massa terhadap efisiensi mesin refrigerasi. Tambovtsev dan Quack (2005) melalui eksperimennya dengan R507a dan amonia menegaskan bahwa pada temperatur kondensasi yang tinggi penggunaan LSHX dapat meningkatkan kinerja mesin refrigerasi. Penggunaan LSHX pada mesin refrigerasi dengan 19 jenis refrigeran juga telah disimulasikan oleh Mastruola (2007). Fokus tinjauan pada simulasi ini lebih ditujukan pada pengaruh sifat termodinamika refrigeran terhadap efektifitas penukar kalor.

\section{METODOLOGI}

Penelitian ini difokuskan pada pengaruh penggunaan Liquid to Gas Heat Exchanger pada 
mesin refrigerasi AC Split menggunakan refrigeran hidrokarbon yang dikenal sebagai refrigeran ramah lingkungan. Beberapa parameter yang dibutuhkan antara lain adalah temperatur dan tekanan evaporasi, temperatur dan tekanan kondensasi, kemudian temperatur suction dan sisi liquid yang dipengaruhi oleh efektifitas penukar kalor. Berikutnya adalah temperatur dischrage yang disamping dipengaruhi temperatur suction, juga dipengaruhi oleh efisiensi isentropis dari proses kompresi oleh kompresor sendiri.

Pengolahan data dilakukan dengan menggunakan formula yang diberikan pada persamaan berikut.

Efek refrigerasi, atau efek pendinginan didefinisikan sebagai selisih entalpi refrigeran keluaran dan masukan evaporator:

$q_{e}=h_{1}-h_{4}$

Kerja kompresor spesifik, $w_{k}$, didefinisikan sebagai selisih entalpi refrigeran keluaran dan masukan kompresor:

$$
w_{k}=h_{2}-h_{1}
$$

Sementara itu, pembuangan panas oleh kondenser, $q_{c}$, dapat dihitung dengan

$q_{c}=h_{3}-h_{2}$

Dari besaran pertama dan kedua dapat dihitung koefisien kinerja (coefficient of performance, $C O P$ ) sistem refrigerasi, yang merupakan perbandingan antara efek refrigerasi dengan kerja kompresor

$$
C O P=\frac{h_{1}-h_{4}}{h_{2}-h_{1}}
$$

Kapasitas pendinginan evaporator dapat dicari dari hasilkali antara selisih entalpi keluaran dan masukan evaporator dengan laju aliran massa refrigeran, atau

$$
Q_{e}=\dot{m}\left(h_{1}-h_{4}\right)
$$

di mana $\dot{m}$ adalah laju aliran massa refrigeran. Dengan cara yang sama, kapasitas kompresor dapat dihitung dari hasilkali selisih entalpi keluaran dan masukan kompresor dengan laju aliran massa refrigeran, atau

$W_{k}=\dot{m}\left(h_{2}-h_{1}\right)$

Kerja kompresor spesifik pada mesin pendingin yang menggunakan $L S H X$ dihitung dengan:

$$
w_{K, L S H X}=h_{2^{\prime}}-h_{1^{\prime}}
$$

Dengan memasukkan laju aliran massa refrigeran, kapasitas pendinginan dan kapasitas kompresor dapat dihitung dengan
$Q_{e, L S H X}=\dot{m}_{L S H X}\left(h_{1^{\prime}}-h_{4^{\prime}}\right)$

di mana $\dot{m}$ adalah laju aliran massa refrigeran. Dengan cara yang sama, kapasitas kompresor dapat dihitung dari hasilkali selisih entalpi keluaran dan masukan kompresor dengan laju aliran massa refrigeran, atau

$$
W_{k, L S H X}=\dot{m}_{L S H X}\left(h_{2^{\prime}}-h_{1^{\prime}}\right)
$$

Koefisien kinerja (COP) mesin refrigerasi dengan LSHX selanjutnya dapat dinyatakan dengan

$$
C O P=\frac{q_{e, L S H X}}{w_{k, L S H X}} \text { atau } C O P=\frac{Q_{e, L S H X}}{W_{k, L S H X}}
$$

Dengan demikian, belum dapat dipastikan apakah koefisien kinerja mesin pendingin akan naik meskipun efek refrigerasi sudah jelas naik.

Efektifitas penukar kalor didefinisikan sebagai berikut :

$$
\varepsilon=\frac{q_{a}}{q_{m}}
$$

dimana :

$q_{a}=$ Perpindahan kalor nyata [W]

$q_{m}=$ Perpindahan kalor maksimum [W]

Perpindahan kalor yang sebenarnya (aktual) dapat dihitung dari energi yang dilepaskan oleh fluida-panas atau energi yang diterima oleh fluida-dingin. perpindahan kalor nyata adalah:

$q_{a}=m_{\mathrm{h}} \mathrm{c}_{\mathrm{ph}}\left(\mathrm{t}_{\mathrm{hi}}-\mathrm{t}_{\mathrm{ho}}\right)$ atau $q_{a}=m_{\mathrm{c}} \mathrm{c}_{\mathrm{pc}}\left(\mathrm{t}_{\mathrm{co}}-\mathrm{t}_{\mathrm{c}}\right)$

dimana

$m_{\mathrm{h}}=$ Laju aliran masa fluida panas $[\mathrm{kg} / \mathrm{s}]$

$m_{\mathrm{c}}=$ Laju aliran masa fluida dingin $[\mathrm{kg} / \mathrm{s}]$

$\mathrm{c}_{\mathrm{ph}}=$ Kalor spesifik fluida panas $\left[\mathrm{J} / \mathrm{kg}^{\circ} \mathrm{C}\right]$

$\mathrm{c}_{\mathrm{pc}}=$ Kalor spesifik fluida dingin $\left[\mathrm{J} / \mathrm{kg}^{\circ} \mathrm{C}\right]$

$\mathrm{t}_{\mathrm{hi}}=$ Temp. fluida panas masuk $\operatorname{LSHX}\left[{ }^{\circ} \mathrm{C}\right]$

$\mathrm{t}_{\mathrm{ho}}=$ Temp. fluida panas keluar $\operatorname{LSHX}\left[{ }^{\circ} \mathrm{C}\right]$

$\mathrm{t}_{\mathrm{ci}}=$ Temperatur fluida dingin masuk $H X\left[{ }^{\circ} \mathrm{C}\right]$

$\mathrm{t}_{\mathrm{co}}=$ Temperatur fluida dingin keluar $H X\left[{ }^{\circ} \mathrm{C}\right]$

Perpindahan kalor maksimum adalah:

$\mathrm{q}_{\max }=(m c)_{\min }\left(\mathrm{t}_{\mathrm{h} i}-\mathrm{t}_{\mathrm{c} i}\right)$

dimana :

$(m \mathrm{c})_{\min }$ adalah nilai terkecil dari :

$C_{c}=m_{\mathrm{c} .} \mathrm{c}_{\mathrm{pc}}$

atau $C_{h}=m_{\mathrm{h} . \mathrm{c}_{\mathrm{ph}}}$

Maka efektifitas penukar kalor untuk aliran berlawanan arah adalah :

$\varepsilon=\frac{\left(t_{h_{i}}-t_{h_{o}}\right)}{\left(t_{h_{i}}-t_{c_{i}}\right)}$ atau $\frac{\left(t_{c_{o}}-t_{c_{i}}\right)}{\left(t_{h_{i}}-t_{c_{i}}\right)}$

Relative Capacity Index (indeks kapasitas relatif) adalah perbandingan kapasitas pendinginan sistem yang menggunakan LSHX dengan sistem 
tanpa menggunakan LSHX. Indeks kapasitas relatif dihitung dengan persamaan:

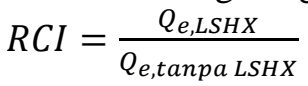

Beberapa besaran yang terkait dengan kinerja mesin refrigerasi akan dihitung dan diselesaikan dengan bantuan perangkat lunak Coolpack dari Department of Mechanical Engineering, Technical University of Denmark dan Reference Fluid Thermodynamic and Transport Properties (REFPROP) dari NIST.

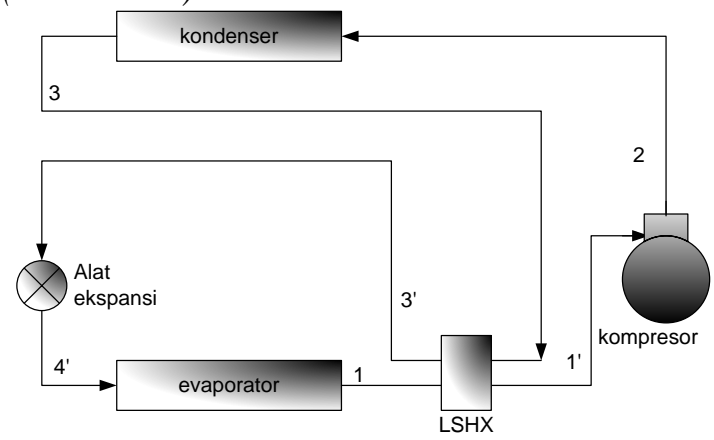

Gambar 5. Skema instalasi sistem refrigerasi menggunakan $L S H X$

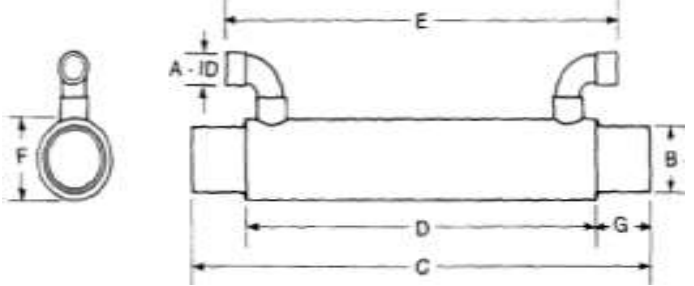

Gambar 6 Double-pipe Liquid Suction Heat Exchanger (LSHX)

\section{HASIL DAN PEMBAHASAN}

\section{A. Efektifitas Liquid-Suction Exchanger \\ Heat}

Efektifitas penukar kalor LSHX ditentukan dengan persamaan (18). Efektifitas penukar yang digunakan mulai dari nol (tanpa menggunakan $L S H X), \quad 0,2 ; 0,4 ; 0,6$ sampai dengan 0,8 . Efektifitas penukar ini akan menentukan perbandingan luasan perpindahan kalor pada $L S H X$, lebih lanjut akan menentukan dimensi LSHX yang digunakan.

Efek Refrigerasi dihitung dengan persamaan (1). Hasil perhitungan efek refrigerasi ditampilkan pada gambar 7. Gambar grafik tersebut menunjukkan bahwa efek refrigerasi meningkat dengan kenaikan efektifitas LSHX, baik pada temperatur kondensasi $40^{\circ} \mathrm{C}$ maupun temperatur kondensasi $45^{\circ} \mathrm{C}$, dengan kenaikan terbesar sekitar 7\%. Efek refrigerasi mempengaruhi kapasitas pendinginan berdasarkan persamaan (5) dan (8).

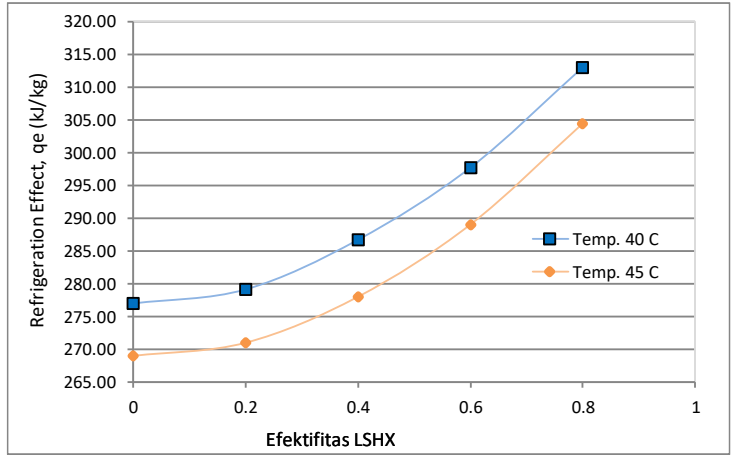

Gambar 7. Efek Refrigerasi pada berbagai nilai efektifitas

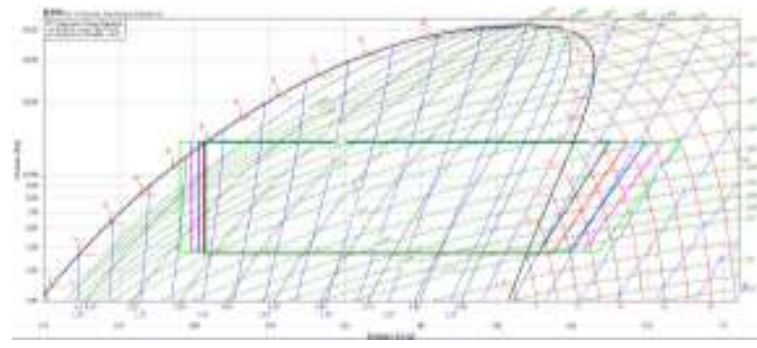

Gambar 8 Plot kerja sistem AC unitary tanpa LSHX dan dengan LSHX pada temperatur kondensasi $40^{\circ} \mathrm{C}$

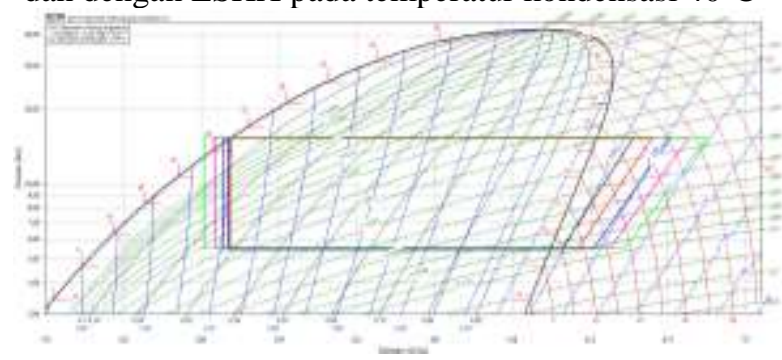

Gambar 9 Plot kerja sistem AC unitary tanpa LSHX dan dengan LSHX pada temperatur kondensasi $45^{\circ} \mathrm{C}$

B. Kerja Kompresi

Kerja kompresi refrigeran dihitung dengan persamaan (2) dan (7). Hasil perhitungan efek refrigerasi ditampilkan pada gambar 8. Gambar grafik tersebut menunjukkan bahwa kerja kompresi juga meningkat dengan naiknya efektifitas LSHX, pada kedua temperatur kondensasi. Terlihat pula bahwa kenaikan kerja kompresi pada temperatur kondensasi yang lebih tinggi $\left(45^{\circ} \mathrm{C}\right)$ lebih tajam dibandingkan dengan kenaikan kerja kompresi pada temperatur kondensasi yang lebih rendah $\left(40^{\circ} \mathrm{C}\right)$ dengan kenaikan terbesar sekitar $19 \%$ pada penggunaan LSHX dengan efektifitas 0,6 . Kerja kompresi ini akan mempengaruhi konsumsi daya kompresor berdasarkan persamaan (5) dan (7). Kedua parameter ini (efek refrigerasi dan kerja kompresi akan menetukan koefisien kinerja (COP) refrigeran berdasar persamaan (4) dan (10). 


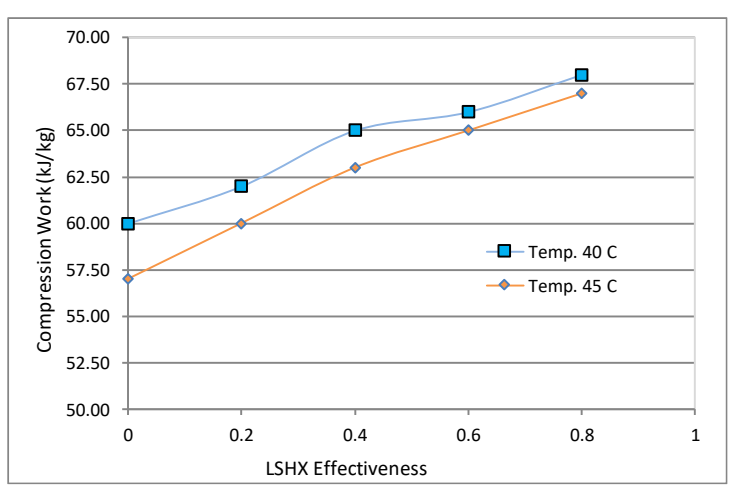

Gambar 10 Kerja Kompresi pada berbagai nilai efektifitas

C. Coefficient of Performance (COP)

Koefisien kinerja (COP) refrigeran dihitung dengan persamaan (4) dan (10). Hasil perhitungan COP di tampilkan pada gambar 11. Pada gambar grafik tersebut terlihat bahwa secara umum penggunaan $L S H X$ pada sistem AC Split menggunakan refrigeran Hidrokarbon kurang menguntungkan, karena rata-rata nilai COP sistem yang menggunakan LSHX dibawah nilai COP sistem yang tidak menggunakan LSHX. Hal ini menunjukkan kenaikan kerja kompresi yang lebih progesif (sekitar 19\%) dari pada kenaikan efek refrigerasi refrigeran (sekitar 7\%). Dari grafik juga terlihat bahwa penurunan nilai COP pada pada temperatur kondensasi yang lebih tinggi $\left(45^{\circ} \mathrm{C}\right)$ lebih tajam dibandingkan dengan penurunan $\mathrm{COP}$ pada temperatur kondensasi yang lebih rendah $\left(40^{\circ} \mathrm{C}\right)$.

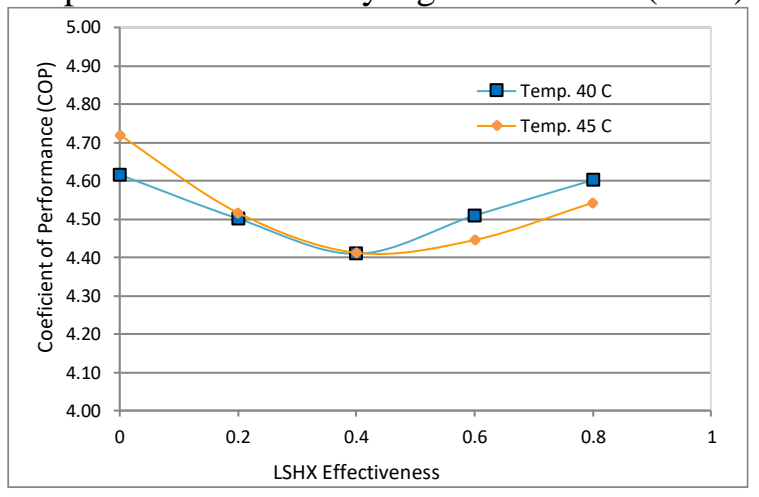

Gambar 11 Koefisien Kinerja (COP) pada berbagai nilai efektifitas

D. Indeks Kapasitas Relatif

Indeks kapasitas relatif dihitung dengan persamaan (18). Hasil perhitungan indeks kapasitas relatif ditampilkan pada gambar 12 . Dari gambar tersebut diperoleh bahwa secara umum penggunaan LSHX pada sistem AC unitary dengan refrigeran hidrokarbon malah menurunkan kapasitas pendinginan, dengan penurunan terbesar pada saat menggunakan LSHX dengan efektifitas 0,6 (sebesar 5\%). Hal ini mengkonfirmasi penurunan $\mathrm{COP}$ yang telah dibahas sebelumnya Penurunan ini disebabkan oleh turunnya laju aliran massa refrigeran masuk kompresor karena turunnya massa jenis/naiknya volume spesifik refrigeran disisi isap (akibat kenaikan superheat/naiknya temperatur isap) kompresor. Kenaikan temperatur ini terjadi karena refrigeran menyerap kalor dari refrigeran disisi liquid yang mempunyai temperatur lebih tinggi. Dari grafik juga terlihat bahwa penurunan kapasitas lebih besar terjadi pada sistem dengan temperatur kondensasi yang tinggi $\left(45^{\circ} \mathrm{C}\right)$ dibandingkan pada sistem dengan temperatur kondensasi yang rendah $\left(40^{\circ} \mathrm{C}\right)$.

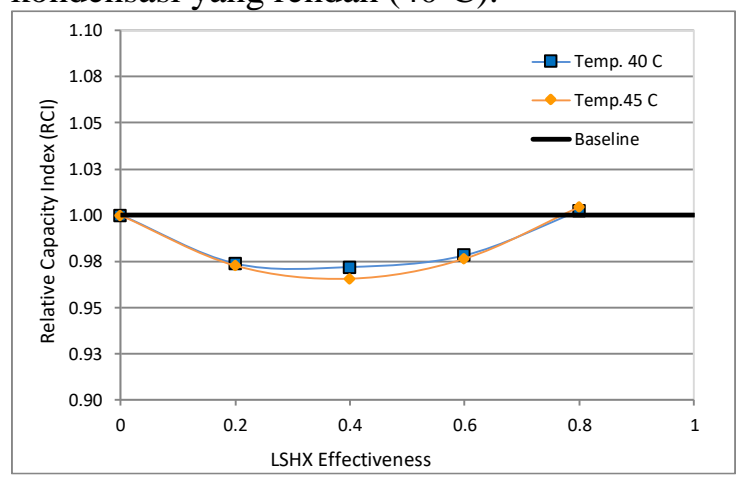

Gambar 12 Indeks Kapasitas Relatif pada berbagai Efektifitas LSHX

\section{KESIMPULAN}

1) Penggunaan Liquid-Suction Heat Exchanger dapat meningkatkan efek refrigerasi refrigeran hidrokarbon sebesar $7 \%$.

2) Penggunaan Liquid-Suction Heat Exchanger juga menaikkan kerja kompresi refrigeran sampai $19 \%$.

3) Penggunaan Liquid-Suction Heat Exchanger menurunkan COP dari sistem.

4) Penggunaan Liquid-Suction Heat Exchanger juga menurunkan kapasitas pendinginan sekitar 5\%.

5) Penurunan kinerja lebih besar terjadi pada sistem dengan temperatur kondensasi yang lebih tinggi.

\section{Daftar Pustaka}

Pérez-Lombard L, Ortiz J, Pout C. 2008; “A Review on Buildings Energy Consumption Information. Energy and Buildings", 40(3): 394-398.

L. Maclaine-cross \& E. Leonardi, 1996; "Comparative Performance of Hydrocarbon Refrigerants", I.I.F. - I.I.R. - 
Commissions E2, E1, B1, B2, 11th to 14th February - Melbourne (Australia)

René Van Gerwen, Alan Gerrard, Fabio Roberti, 2008; "Ice Cream Cabinets Using A Hydrocarbon Refrigerant: From Technology Concept To Global Rollout", 8th IIR Gustav Lorentzen Conference on Natural Working Fluids, Copenhagen

Australian Institute Of Refrigeration, Air Conditioning And Heating, "Natural Refrigerants Case Studies";

http://www.ammonia21.com/files/papers/ airahnatural-refrigerants-case-studies.pdf

M. Mohanraj, S. Jayaraj and C. Muraleedharan; "Comparative assessment of environmentfriendly alternatives to R134a in domestic refrigerators, Energy Efficiency", Volume 1, Number 3, 189-198

Practical Application of Refrigerants R 600a and R 290 in Small Hermetic Systems, Danfoss Refrigeration \& Air Conditioning Division

Mastrullo, R., Mauro, Tino, S. and Vanoli, G.P., 2007, "A chart for predicting the possible advantage of adopting a suction/liquid heat exchanger in refrigerating system", Applied Thermal Engineering, Vol. 27 pp. 24432448.

Pottker, G. and Hrnjak, P., 2012, "Effect of condenser subcooling of the performance ov vapor compression systems: Experimental and numerical investigation", International Refrigeration and Air Conditioning Conference, Purdue University, July 16-19, pp. 1-10, R031.

Pottker, G. and Hrnjak, P., 2015, “Experimental investigation of the effect condenser subcooling in R134a and R1234yf airconditioning systems with and without internal heat exchanger", International Journal of Refrigeration, Vol. 50 pp. 104113.

Lemmon, E.W., Huber M.L., and McLinden, M.O., 2013; "Reference fluid thermodynamic and transport properties (REFPROP)", NIST Standard Reference Database 23, v.9.1, National Institute of Standards 2013, Gaithersburg MD, USA. 